\title{
KORELASI ANTARA TEMPERATUR PEMADATAN PADA CAMPURAN ASPAL BETON HASIL DAUR ULANG TERHADAP STABILITAS MARSHALL
}

\section{Correlation Between Compaction Temperature In Mixed Asphalt Concrete Recycling of Stability of Marshall}

\author{
Alik Ansyori Alamsyah \\ Jurusan Teknik Sipil Fakultas Teknik - Universitas Muhammadiyah Malang \\ Alamat korespondensi : Jalan Raya Tlogomas 246 Malang 65144 \\ Email : alik.syah@yahoo.com
}

\begin{abstract}
Road improvement by adding an additional layer that will result in continuous thicker pavement layer thickness and material required dwindling. Besides, with the amount of dredging mix pavement roads that are not used in some places add to the waste pile. With treatment using pavement recycling technologies (recycling) is an alternative to overcome this problem because it has several advantages such as pavement can restore and maintain strength and overcome the geometric dependence of new materials. The addition of new material and additional material or material scratch mark on the old pavement is an alternative to increase the carrying capacity of the material scratchmark. The study was conducted at the Laboratory of University of Muhammadiyah Malang Highway. The quality of asphalt concrete mixtures with the addition of recycled asphalt can only be known through the Marshall test results (stability, melting plastic, the results for the marshal, and the cavity in the mix). Used asphalt is asphalt with a penetration of 80/100 is a variation of temperature to be used is $130^{\circ} \mathrm{C}, 12^{\circ} \mathrm{C}, 110^{\circ} \mathrm{C}, 100^{\circ} \mathrm{C}, 90^{\circ} \mathrm{C}$ and $80^{\circ} \mathrm{C}$. From the results of the research can be seen that the decrease in the solidification temperature will decrease stability, Marshall Quotient for the entire binder content. For Flow values at a temperature of $130^{\circ} \mathrm{C}$ compaction - $80^{\circ} \mathrm{C}$ showed an increase.
\end{abstract}

Keywords : Temperature Compaction, Asphalt Concrete Recycling results

\begin{abstract}
Abstrak
Peningkatan jalan dengan cara penambahan lapis tambahan yang terus menerus akan mengakibatkan tebal lapis perkerasan semakin tebal dan bahan yang diperlukan semakin menipis. Disamping itu dengan banyaknya campuran perkerasan dari hasil pengerukan jalan yang sudah tidak terpakai menambah tumpukan limbah dibeberapa tempat. Dengan penanganan yang menggunakan teknologi daur ulang perkerasan (recycling) merupakan suatu alternatif untuk mengatasi masalah ini karena memiliki beberapa keuntungan seperti dapat mengembalikan kekuatan perkerasan dan mempertahankan geometrik jalan serta mengatasi ketergantungan akan material baru. Penambahan bahan baru dan atau bahan tambahan pada material bekas garukan perkerasan lama merupakan salah satu alternatif untuk meningkatkan daya dukung dari material bekas garukan. Penelitian dilakukan di Laboratorium Jalan Raya Universitas Muhammadiyah Malang. Kualitas campuran aspal beton hasil daur ulang dengan penambahan aspal baru dapat diketahui melalui hasil uji Marshall (stabilitas, kelelehan plastis, hasil bagi marshall, serta rongga dalam campuran). Aspal yang digunakan adalah aspal dengan penetrasi $80 / 100$ sedang variasi temperatur yang akan digunakan adalah $130{ }^{\circ} \mathrm{C}, 120^{\circ} \mathrm{C}, 110^{\circ} \mathrm{C}, 100^{\circ} \mathrm{C}$, $90{ }^{\circ} \mathrm{C}$ dan $80^{\circ} \mathrm{C}$. Dari hasil penelitian dapat dilihat bahwa penurunan temperatur pemadatan akan berakibat turunnya stabilitas, Marshal Quotient untuk seluruh kadar aspal. Untuk nilai Flow pada temperatur pemadatan $130^{\circ} \mathrm{C}-80^{\circ} \mathrm{C}$ menunjukkan peningkatan.
\end{abstract}

Kata Kunci : Temperatur Pemadatan, Aspal Beton Hasil Daur Ulang.

\section{PENDAHULUAN}

Volume dan beban kendaraan cenderung terus bertambah sehingga diperlukan suatu inovasi dalam bidang pemeliharaan jalan guna mempertahankan atau menambah umur rencana jalan dalam melayanani beban lalu-lintas. Disadari bahwa dibutuhkan infrastruktur yang kuat untuk 
menyehatkan ekonomi dan jalan yang baik merupakan bagian yang sangat vital dari infrastruktur ini. Jika dana tidak mencukupi maka metode rehabilitasi jalan yang lebih efektif dan efisien harus didapatkan. Peningkatan jalan dengan cara penambahan lapis tambahan yang terus menerus akan mengakibatkan tebal lapis perkerasan semakin tebal dan bahan yang diperlukan semakin menipis.

Pada jalan Kol. Sugiono, panjang jalan yang dikeruk perkerasannya adalah $3 \mathrm{~km}$ dengan lebar jalan 10 meter, maka didapat limbah perkerasan sebanyak \pm 1.500 ton. Dengan limbah sebanyak tersebut apabila dibiarkan maka kedepan pasti akan menimbulkan permasalahan yang lebih kompleks.

Adanya kerusakan-kerusakan kecil pada jalan beraspal (retak, lubang, alur dan sebagainya) billa dibiarkan, lama-kelamaan akan menjadikan biaya perbaikan menjadi semakin mahal. Banyak faktor yang menjadi penyebab kerusakan tersebut, antara lain labilnya tanah dasar dan lapis pondasi di bawahnya, beban lalu lintas, iklim dan cuaca, dan rendahnya mutu campuran aspal tersebut, serta kurangnya pemeliharaan. Salah satu cara untuk menjaga kualitas perjalanan lalu lintas tetap lancar ialah dengan menyediakan permukaan jalan yang baik, dengan cara melakukan pelapisan ulang (overlay).

Setiap kali dilakukan pelapisan ulang selalu menambah elevasi jalan yang bersangkutan, sehingga elevasi permukaan jalan makin lama semakin tinggi, hal ini kadang tidak diinginkan. Untuk mengatasi masalah tersebut dilakukan dengan cara mengganti bagian lapis permukaan jalan dengan lapisan yang baru. Oleh karena itu lapisan permukaan yang lama perlu dikeruk terlebih dahulu sesuai dengan ketebalan yang akan ditambahkan kemudian. Pembongkaran tersebut dimaksudkan agar elevasi jalan tidak semakin tinggi, sehingga tidak mempengaruhi elevasi bahu jalan. Disisi lain dengan adanya pembongkaran tersebut akan mengakibatkan bertumpuknya limbah hasil pengerukan lapisan aspal beton tersebut. Sehingga perlu dilakukan rekayasa - rekayasa tertentu yang akan dapat memanfaatkan tumpukan limbah tersebut.

Kandungan aspal pada material bekas yang sudah berkurang daya ikatnya bila dikombinasikan dengan aspal baru akan diperoleh kembali daya ikat yang baik. Material bekas yang dimaksud adalah material pada lapisan permukaan jalan yang sudah rusak dan masih dapat digunakan kembali sebagai bahan campuran aspal beton melalui proses daur ulang. Berkurangnya kadar aspal karena aus akibat gesekan roda kendaraan dan faktor oksidasi, mengakibatkan aspal kehilangan daya ikatnya sehingga aspal tidak mampu lagi mengikat butiran agregat dengan baik, yang membuat agregat tersebut terlepas dan jalan menjadi rusak.

Untuk mendapatkan campuran aspal dengan stabilitas yang baik maka unsur-unsur pembentuk campuran aspal harus memenuhi spesifikasi yang telah ditetapkan. Oleh karena itu penelitian ini dimaksudkan untuk mengetahi sejauh mana karakteristik aspal beton hasil daur ulang dapat digunakan kembali sebagai lapis permukaan dengan perlakuan variasi temperature pemadatan.

Adapun hipotesa dalam penelitian ini adalah Penggunaan variasi temperature pemadatan pada campuran perkerasan Aspal Beton hasil daur ulang akan meningkatkan karakteristik Marshall “.

\section{METODE PENELITIAN}

\section{Umum}

- Penelitian material Asbuton Hasil Daur Ulang meliputi :

- Asbuton

- Agregat

- Aspal minyak

- Temperatur pada waktu pemadatan benda uji direncanakan yaitu $130^{\circ} \mathrm{C}, \quad 120^{\circ} \mathrm{C}, 110^{\circ} \mathrm{C}$, $100{ }^{\circ} \mathrm{C}, 90^{\circ} \mathrm{C}$ dan $80{ }^{\circ} \mathrm{C}$.

- Pelaksanaan test marshall dilakukan untuk mencari harga - harga stabilitas, flow, marshall Question, density, rongga dalam campuran, rongga antar agregat dan rongga terisi bitumen

\section{Tempat Penelitian}

Penelitian Campuran Perkerasan Laston Hasil Daur Ulang ini telah dilaksanakan Laboratorium Teknik Sipil Universitas Muhammadiyah Malang. Adapun Alur dari penelitian ini seperti pada Gambar 1. 


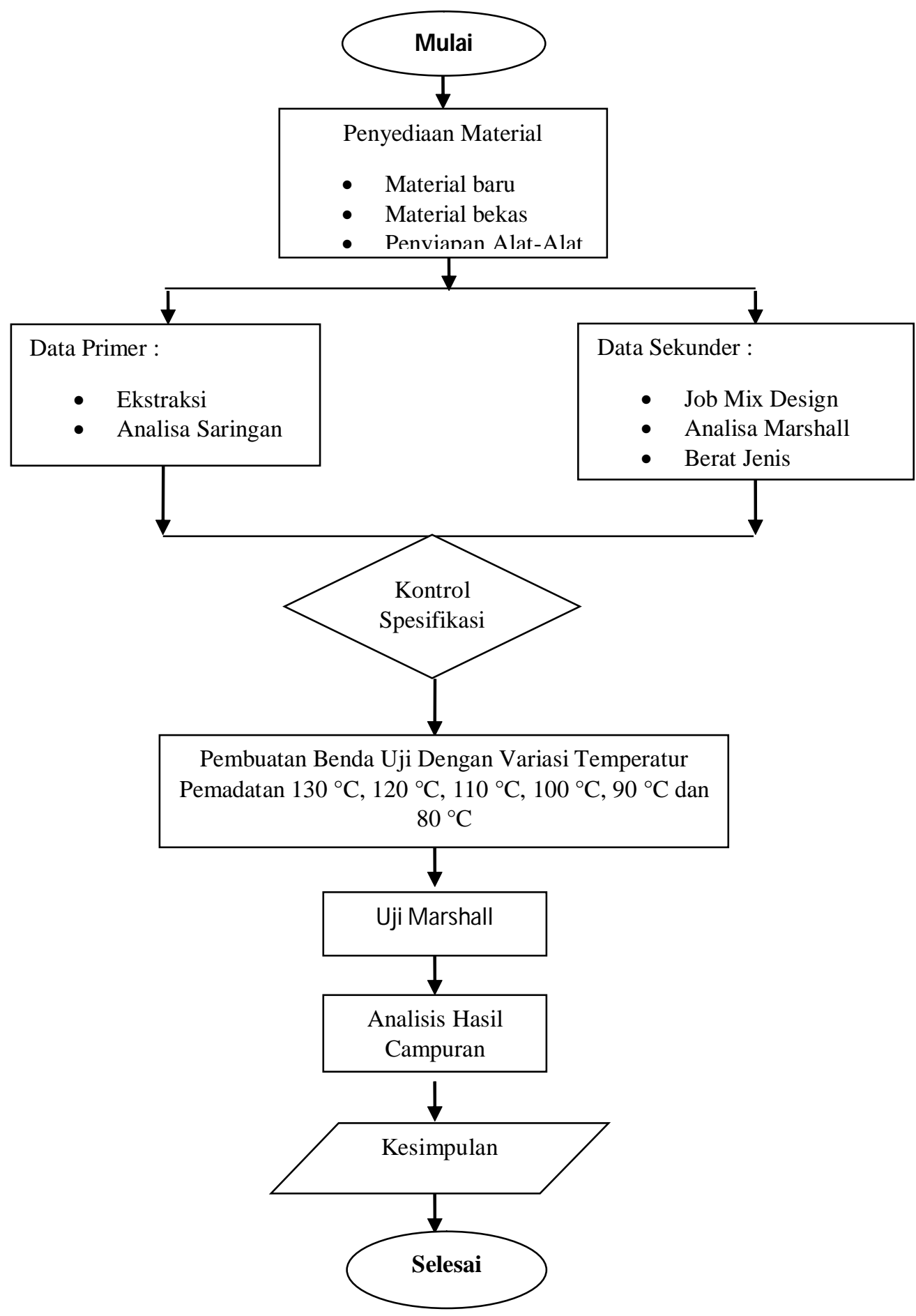

Gambar 1. Diagram Alur Penelitian

\section{Penyediaan Material}

- Bahan bekas galian lapis permukaan jalan, yaitu di jalan Kol. Sugiono.

- Bensin untuk pengujian ekstraksi.

- Aspal pen 60/80 untuk bahan tambah.

\section{Penyiapan Alat}

- Peralatan ekstraksi terdiri dari ekstraktor lengkap dengan bowl dan tutupnya, timbangan dengan ketelitian 0,01 gr; oven; saringan; mesin penggoncang saringan; alat pemisah contoh.

- Peralatan analisis saringan terdiri dari satu set saringan (No. 12,5; 9,5; 4,75; 2,36; 1,18; 0,6; $0,3 ; 0,15 ;$ dan 0,075$)$

- Peralatan pembuatan benda uji terdiri dari satu set cetakan dengan diameter $100 \mathrm{~mm}$ dan tinggi $75 \mathrm{~mm}$, pemadat manual dengan berat 4,536 $\mathrm{kg}$ dengan tinggi jatuh $45,7 \mathrm{~cm}$, ejector untuk mengeluarkan benda uji dari cetakan. 
- Peralatan perendaman (waterbath)

- Peralatan uji Marshall, yang terdiri dari alat penekan yang berbentuk lengkung, cincin pengujian dengan kapasitas 5000 lbs (sekitar $2500 \mathrm{~kg}$ ) dan arloji tekan dengan ketelitian $0,0024 \mathrm{~cm}$ dan arloji penunjuk kelelehan (flow).

\section{Data Proyek}

Yaitu merupakan data-data yang diperoleh dari instansi terkait yang berisi tentang data riil di lapangan. Yang meliputi :

- Job Mix Design

- Analisa Marshall

- $\quad$ Berat Jenis masing - masing material

Data-data tersebut di atas dipakai sebagai pembanding untuk pembuatan campuran aspal beton daur ulang.

\section{Pembuatan benda uji}

Pembuatan benda uji campuran panas, bahan bekas galian permukaan jalan ditimbang untuk mendapatkan satu benda uji (1200 gr). Bahan tersebut selanjutnya dipanaskan agar aspal meleleh dan ditambahkan pula sejumlah aspal. Selanjutnya bahan dimasukkan ke dalam cetakan dan dipadatkan dengan cara ditumbuk. Kadar aspal yang ditambahkan bervariasi yang nilainya masing-masing : $0.5 \% ; 1 \% ; 1.5 \% ; 2 \%$; dan $2.5 \%$.

\section{HASIL DAN PEMBAHASAN}

\section{Material}

Material reclaimed yang merupakan hasil garukan lapis permukaan di Jalan Kol. Sugiono Malang diekstraksi dengan prosedur sesuai dengan SNI (Standart Nasional Indonesia). Pemeriksaan ekstraksi dilakukan terhadap reclaimed beton aspal untuk memisahkan aspal dan agregat, jadi kadar aspal dapat diketahui..

Material bekas di oven selama 30 menit pada suhu $110^{\circ} \mathrm{C}$. setelah itu diambil secukupnya (@ 1200 gr) dan dimasukkan kedalam bowl yang sudah ditimbang. Bowl dan benda uji dimasukkan ke dalam alat ekstraktor kemudian bensin dituangkan penuhpenuh, ditutup dan dilapisi kertas filter, didiamkan selama 10 menit dan kemudian diputar selama 1 menit. Bensin dituangkan lagi penuh dan didiamkan selama 5 menit dan diputar lagi selama 1 menit. Pekerjaan ini diulang kembali sampai bensin yang keluar jernih betul. Setelah jernih bowl dan benda uji dikeluarkan, kemudian di oven. Setelah di oven didinginkan dan ditimbang baik sisa larutan dan kertas filternya.

Tabel 1. Hasil ekstraksi reclaimed material

\begin{tabular}{|c|c|c|c|c|c|}
\hline \multicolumn{2}{|c|}{ Pemeriksaan } & \multirow{2}{*}{$\begin{array}{c}\begin{array}{c}\text { Benda } \\
\text { Uji I }\end{array} \\
\text { (gram) } \\
38\end{array}$} & \multirow{2}{*}{$\begin{array}{c}\begin{array}{c}\text { Benda Uji } \\
\text { II } \\
\text { (gram) }\end{array} \\
38.2\end{array}$} & \multirow{2}{*}{$\begin{array}{c}\begin{array}{c}\text { Benda Uji } \\
\text { III } \\
\text { (gram) }\end{array} \\
38.2\end{array}$} & \multirow{2}{*}{$\begin{array}{c}\begin{array}{c}\text { Benda Uji } \\
\text { IV } \\
\text { (gram) }\end{array} \\
38.1\end{array}$} \\
\hline $\begin{array}{l}\text { Berat Kertas Filter } \\
\text { (gram) }\end{array}$ & (A) & & & & \\
\hline $\begin{array}{l}\text { Berat Benda Uji }+ \\
\text { Kertas Filter Sblm } \\
\text { Diekstraksi (gram) }\end{array}$ & (B) & 1238 & 1238.2 & 1238.2 & 1238.1 \\
\hline $\begin{array}{l}\text { Berat Benda Uji Sblm } \\
\text { Diekstraksi (gram) }\end{array}$ & $(C=B-A)$ & 1200 & 1200 & 1200 & 1200 \\
\hline $\begin{array}{l}\text { Berat Benda Uji + } \\
\text { Kertas Filter Sesudah } \\
\text { Diekstraksi (gram) } \\
\text { Berat Benda Uji }\end{array}$ & (D) & 1174 & 1167.2 & 1171.2 & 1164.1 \\
\hline $\begin{array}{l}\text { Setelah Diekstraksi } \\
\text { (gram) }\end{array}$ & $(\mathrm{E}=\mathrm{D}-\mathrm{A})$ & 1136 & 1129 & 1133 & 1126 \\
\hline Kadar Aspal & $\begin{array}{l}\{(C-E) / \\
C\} \times 100 \%\end{array}$ & 5.33 & 5.92 & 5.58 & 6.17 \\
\hline Kadar Aspal Rata-rata & $(\%)$ & & & 75 & \\
\hline
\end{tabular}


Dari agregat dan aspal yang telah dipisahkan, sifat fisik dari masing-masing material dapat diuji, kemudian diperiksa terhadap spesifikasi sehingga dapat ditentukan kemungkinan material reclaimed masih dapat digunakan dalam membuat campuran beraspal. Berdasarkan hasil ekstraksi yang di dapat sisa kadar aspal rata-rata adalah $5.75 \%$, maka selama kurun waktu 5 tahun umur rencana telah kehilangan $1.05 \%$ kadar aspal dari kadar aspal JMF yaitu sebesar $6.8 \%$.

\section{Analisa Saringan}

Setelah pengujian ekstraksi didapatkan batuan sebagai penyusun bahan perkerasan. Tujuan dari pemeriksaan analisa saringan terhadap agregat material hasil daur ulang adalah untuk memperoleh gradasi dari agregat hasil ekstraksi dan melihat kondisinya dengan membandingkan gradasi tersebut dengan spesifikasi yang digunakan. Hasil analitis untuk 4 sampel yang diteliti disajikan pada Tabel 2, spesifikasi yang dipakai adalah spesifikasi AC-BC (AC-Binder Course) dari Dinas Bina Marga.

Tabel 2. Analisa Saringan Benda Uji 1 (1136 gram)

\begin{tabular}{cccccccc}
\hline $\begin{array}{c}\text { Ukuran } \\
\begin{array}{c}\text { Saringan } \\
(\mathrm{mm})\end{array}\end{array}$ & $\begin{array}{c}\text { Berat } \\
\text { Tertahan } \\
\text { (gram) }\end{array}$ & $\begin{array}{c}\text { Kumulatif } \\
\text { Tertahan } \\
\text { (gram) }\end{array}$ & $\begin{array}{c}\text { Jumlah } \\
\text { Tertahan }\end{array}$ & $\begin{array}{c}\% \\
\text { Lolos }\end{array}$ & Min & Maks & $\begin{array}{c}\text { Spesifikasi } \\
\text { Campuran } \\
\%\end{array}$ \\
\hline 25.400 & 0 & 0 & 0 & 100 & 100 & 100 \\
19.100 & 88.5 & 88.5 & 7.79 & 92.21 & 90 & 100 & 100 \\
12.700 & 126.3 & 214.8 & 18.91 & 81.09 & maks. 90 & 87.48 \\
9.520 & 264.2 & 479 & 42.17 & 57.83 & & & 78.33 \\
4.760 & 114.2 & 593.2 & 52.22 & 47.78 & & & 57.42 \\
2.380 & 98.3 & 691.5 & 60.87 & 39.13 & 23 & 49 & 42.55 \\
1.190 & 74.9 & 766.4 & 67.46 & 32.54 & & & 31.17 \\
0.599 & 91.5 & 857.9 & 75.52 & 24.48 & & & 21.84 \\
0.297 & 80.6 & 938.5 & 82.61 & 17.39 & & & 14.96 \\
0.149 & 79.6 & 1018.1 & 89.62 & 10.38 & & & 8.58 \\
0.074 & 51.1 & 1069.2 & 94.12 & 5.88 & 4 & 8 & 4.73 \\
Pan & 66.8 & 1136 & 100.00 & 0.00 & & & \\
\hline
\end{tabular}

Sumber : Hasil Penelitian.

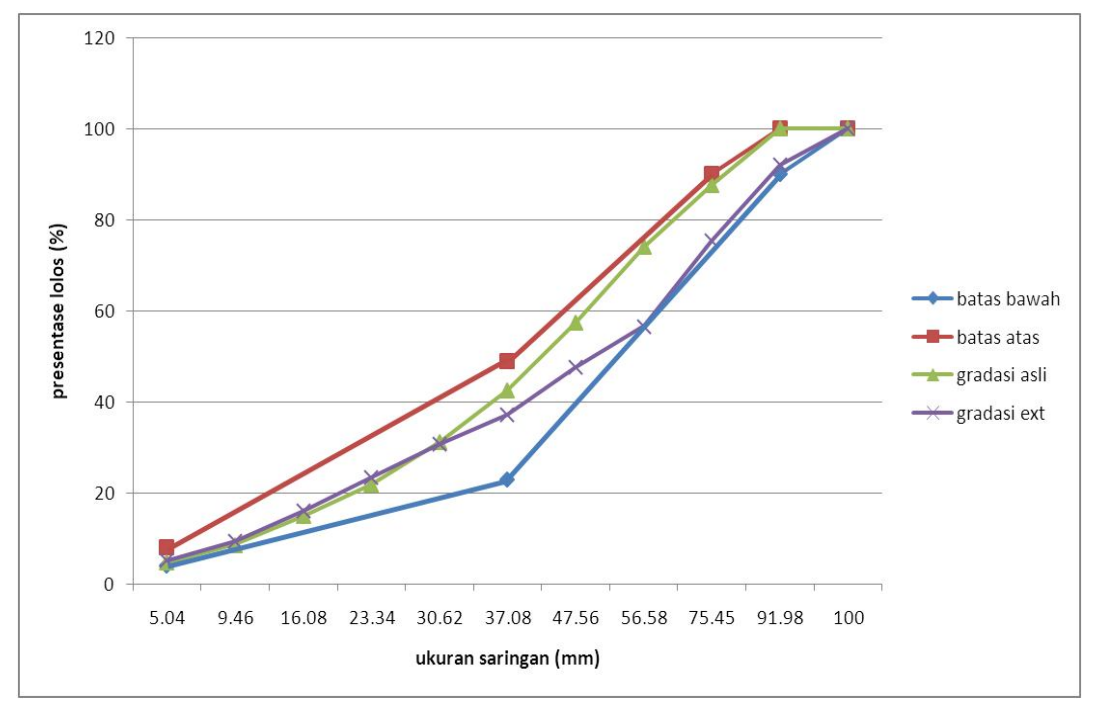

Gambar 2. Gradasi agregat hasil ekstraksi rata-rata

Secara umum dari Gambar 1, dapat dilihat bahwa agregat hasil ekstraksi ini, jika dibandingkan dengan gradasi perkerasan desain awal sudah mengalami perubahan, terutama pada agregat halus. 
Berubahnya ukuran agregat menjadi lebih kecil ini disebabkan oleh faktor pembebanan lalu lintas. Namun dari perubahan ini secara umum, agregat hasil ekstraksi masih memenuhi dalam batas spesifikasi yang telah ditentukan.

Dari grafik analisa saringan diperoleh $\mathrm{D}_{30}=$ $1.35 \mathrm{~mm}, \mathrm{D}_{60}=16.25 \mathrm{~mm}, \mathrm{D}_{10}=1.61 \mathrm{~mm}$, Nilai $_{\mathrm{u}}=$ $16.25 / 1.61=10.09, \mathrm{C}_{\mathrm{c}}=1.35^{2} /(16.25 \times 1.61)=0.06$. Berdasarkan nilai $\mathrm{C}_{\mathrm{c}}$ dan $\mathrm{C}_{\mathrm{u}}$ termasuk klasifikasi poorly graded atau bergradasi jelek, hal ini disebabkan oleh adanya perubahan ukuran agregat menjadi lebih kecil, yang diakibatkan oleh tingginya volume lalu lintas yang melewati jalan tersebut.

\section{Pemeriksaan Agregat Hasil Ekstraksi}

Hasil dari pengujian sifat-sifat fisik atau karakteristik agregat kasar, agregat halus dan filler dari hasil ekstraksi yang digunakan dalam campuran seperti terlihat pada Tabel 3. Pengujian yang dilakukan hanya sebatas berat jenis dan penyerapan agregat, hal ini dikarenakan keterbatasan reclaimed beton aspal. Hasil pengujian berat jenis dan penyerapan agregat menunjukkan bahwa agregat yang digunakan memenuhi spesifikasi yang disyaratkan.

Dilihat dari hasil pada Tabel 3, berat jenis agregat hasil ekstraksi dengan data JMF relatif berbeda, berat jenis agregat hasil ekstraksi cenderung memiliki nilai yang lebih kecil dibandingkan data JMF, sedangkan penyerapan agregat memiliki perbedaan yang cukup signifikan yaitu agregat hasil ekstraksi memiliki nilai penyerapan jauh lebih kecil dibandingkan data JMF, hal ini disebabkan sebagian besar pori agregat hasil ekstraksi telah terisi aspal.

Tabel 3. Hasil Pemeriksaan Agregat

\begin{tabular}{clcccc}
\hline No. & \multicolumn{1}{c}{ Uraian Pengujian } & Satuan & Persyaratan & Hasil & $\begin{array}{c}\text { Data } \\
\text { JMF }\end{array}$ \\
\hline 1 & Agregat Kasar (tertahan \#4) & & & & \\
& Berat Jenis Bulk & gr/cc & min. 2.5 & 3.16 & 2.56 \\
& Berat Jenis SSD & gr/cc & min. 2.5 & 3.61 & 2.68 \\
& Berat Jenis Semu & gr/cc & min. 2.5 & 5.75 & \\
& Penyerapan & $\%$ & maks. 3 & 0.14 & \\
2 & Agregat Halus (lolos \#4) & & & & \\
& Berat Jenis Bulk & gr/cc & min. 2.5 & 3.73 & 2.61 \\
& Berat Jenis SSD & gr/cc & min. 2.5 & 3.79 & 2.72 \\
& Berat Jenis Semu & gr/cc & min. 2.5 & 4.00 & \\
& Penyerapan & $\%$ & maks. 3 & 0.32 & \\
\hline
\end{tabular}

Sumber : Hasil Penelitian.

Berat jenis yang kecil akan mempunyai volume yang besar sehingga dengan berat yang sama akan membutuhkan aspal yang banyak. Agregat hendaknya sedikit berpori agar dapat menyerap aspal, sehingga terbentuklah ikatan mekanis antara film aspal dan butiran batu. Agregat berpori banyak akan menyerap aspal besar pula sehingga tidak ekonomis.

\section{Pemeriksaan Aspal Baru}

Pengujian fisik pada material aspal dilakukan untuk mengetahui karakteristik aspal jenis pen 60/ 70 yang akan digunakan sebagai aspal tambahan pada campuran recycling. Berdasarkan hasil pengujian fisik pada kondisi asli material aspal dengan penetrasi 60/70 produksi Pertamina yang akan digunakan memenuhi persyaratan yang ditentukan seperti yang terlihat pada Tabel 4 .

Tabel 4 Hasil Pengujian Sifat-Sifat Teknis Aspal

\begin{tabular}{clccc}
\hline \multirow{2}{*}{ No. } & \multicolumn{1}{c}{ Jenis Pengujian } & \multicolumn{3}{c}{ Persyaratan } \\
& & Hasil Uji & Min. & Maks. \\
\hline 1 & Penetrasi, $25^{\circ} \mathrm{C}, 100 \mathrm{gr}, 5$ det, $0,1 \mathrm{~mm}$ & 66 & 60 & 79 \\
2 & Titik Lembek, ${ }^{\circ} \mathrm{C}$ & 49 & 48 & 58 \\
\hline
\end{tabular}




\begin{tabular}{llccc}
\hline 3 & Titik Nyala, ${ }^{\circ} \mathrm{C}$ & 342 & 200 & - \\
4 & Daktilitas, $25^{\circ} \mathrm{C}, 5 \mathrm{~cm} / \mathrm{mnt}, \mathrm{cm}$ & $>100$ & 100 & - \\
5 & Berat Jenis & 1.034 & 1 & - \\
\hline
\end{tabular}

\section{Hasil Analisa Penelitian Pengaruh Temperatur Pemadatan Terhadap Sifat - sifat Campuran}

Tabel 5. Hasil - hasil Penelitian Pengaruh Temperatur Pemadatan Terhadap Sifat - sifat Campuran

\begin{tabular}{|c|c|c|c|c|c|c|c|}
\hline \multirow[t]{2}{*}{ No } & \multirow{2}{*}{$\begin{array}{l}\text { Temperatur } \\
\text { Pemadatan } \\
\left({ }^{\circ} \mathrm{C}\right)\end{array}$} & \multirow{2}{*}{$\begin{array}{c}\text { Kadar } \\
\text { Lateks } \\
(\%)\end{array}$} & \multicolumn{2}{|c|}{ Stabilitas } & \multirow{2}{*}{$\begin{array}{l}\text { Flow } \\
(\mathrm{mm})\end{array}$} & \multirow{2}{*}{$\begin{array}{l}\text { Marshall } \\
\text { Quotient } \\
(\mathrm{kn} / \mathrm{mm})\end{array}$} & \multirow{2}{*}{$\begin{array}{c}\text { Rongga } \\
\text { Udara } \\
(\%)\end{array}$} \\
\hline & & & Dibaca & Disesuaikan & & & \\
\hline \multirow[t]{2}{*}{1} & 80 & 0 & 77 & 1231.34 & 2.05 & 5.889 & 2.177 \\
\hline & & & 81 & 1292.37 & 2.3 & 5.511 & 2.518 \\
\hline \multirow[t]{2}{*}{2} & 80 & 1 & 82 & 1248.17 & 2.9 & 4.22 & 2.86 \\
\hline & & & 90 & 1153.22 & 3.2 & 3.533 & 5.719 \\
\hline \multirow[t]{2}{*}{3} & 80 & 3 & 65 & 943.71 & 5.9 & 1.568 & 2.945 \\
\hline & & & 71 & 986.91 & 5.4 & 1.792 & 3.542 \\
\hline \multirow[t]{2}{*}{4} & 80 & 5 & 150 & 1804.7 & 4.4 & 4.021 & 4.951 \\
\hline & & & 124 & 1961.68 & 1.8 & 10.686 & 4.994 \\
\hline \multirow[t]{2}{*}{5} & 80 & 7 & 120 & 1859.63 & 3.1 & 5.881 & 3.158 \\
\hline & & & 151 & 1895.91 & 3.3 & 5.633 & 5.548 \\
\hline \multirow[t]{2}{*}{6} & 90 & 0 & 130 & 1983.93 & 0.82 & 2.372 & 0.384 \\
\hline & & & 125 & 1905.53 & 0.56 & 3.336 & 0.896 \\
\hline \multirow[t]{2}{*}{7} & 90 & 1 & 110 & 1618.12 & 1.1 & 14.422 & 4.951 \\
\hline & & & 120 & 1859.63 & 1.5 & 12.192 & 4.609 \\
\hline \multirow[t]{2}{*}{8} & 90 & 3 & 92 & 1203.76 & 3.1 & 3.807 & 5.207 \\
\hline & & & 84 & 1179.21 & 4.1 & 2.82 & 5.335 \\
\hline \multirow[t]{2}{*}{9} & 90 & 5 & 76 & 1115.66 & 2.7 & 4.051 & 3.841 \\
\hline & & & 87 & 1130.58 & 2.8 & 3.959 & 4.097 \\
\hline \multirow[t]{2}{*}{10} & 90 & 7 & 82 & 1152.16 & 3 & 3.765 & 8.109 \\
\hline & & & 76 & 1115.66 & 3.1 & 3.582 & 3.969 \\
\hline 11 & 100 & 0 & 151 & 2115.97 & 2.1 & 9.878 & 3.969 \\
\hline \multirow[t]{2}{*}{12} & 100 & 1 & 64 & 1013.12 & 2.88 & 3.449 & 3.372 \\
\hline & & & 76 & 1115.66 & 1.9 & 5.757 & -1.195 \\
\hline \multirow[t]{2}{*}{13} & 100 & 3 & 124 & 1822.99 & 5.1 & 3.504 & 2.603 \\
\hline & & & 113 & 1811.86 & 3.5 & 5.075 & 1.451 \\
\hline \multirow[t]{2}{*}{14} & 100 & 5 & 90 & 1376.06 & 2.8 & 4.818 & -0.683 \\
\hline & & & 88 & 1335.51 & 2.2 & 5.951 & 0.341 \\
\hline \multirow[t]{2}{*}{15} & 100 & 7 & 93 & 1380.91 & 3.3 & 4.103 & 1.494 \\
\hline & & & 85 & 1354.02 & 6.4 & 2.074 & -2.305 \\
\hline \multirow[t]{2}{*}{16} & 110 & 0 & 234 & 3579.88 & 2.4 & 14.624 & 1.451 \\
\hline & & & 210 & 3367.17 & 2.7 & 12.226 & 2.988 \\
\hline \multirow[t]{2}{*}{17} & 110 & 1 & 191 & 2922.04 & 1.05 & 27.283 & 1.707 \\
\hline & & & 191 & 2809.65 & 2.7 & 10.202 & 2.774 \\
\hline 18 & 110 & 3 & 189 & 2585.61 & 3.5 & 7.243 & 6.615 \\
\hline & & & 175 & 2649.51 & 3.1 & 8.379 & 1.28 \\
\hline 19 & 110 & 5 & 153 & 2324.05 & 2.1 & 10.85 & 0.213 \\
\hline & & & 157 & 2389.08 & 2.9 & 8.077 & 1.323 \\
\hline 20 & 110 & 7 & 130 & 1774.25 & 2.6 & 6.69 & 0.64 \\
\hline & & & 168 & 2177.98 & 1.6 & 13.345 & 0.512 \\
\hline 21 & 120 & 0 & 136 & 2078.15 & 1.75 & 11.642 & 1.152 \\
\hline & & & 148 & 2006.73 & 3.3 & 5.962 & 1.024 \\
\hline 22 & 120 & 1 & 161 & 2194.08 & 2.05 & 10.493 & 9.603 \\
\hline & & & 162 & 2195.9 & 4.8 & 4.485 & 6.829 \\
\hline
\end{tabular}




\begin{tabular}{|c|c|c|c|c|c|c|c|}
\hline \multirow[t]{2}{*}{23} & 120 & 3 & 106 & 1450.13 & 3.8 & 3.741 & 2.689 \\
\hline & & & 88 & 1284.15 & 3.3 & 3.815 & 1.622 \\
\hline \multirow[t]{2}{*}{24} & 120 & 5 & 175 & 2649.51 & 0.99 & 26.238 & 1.237 \\
\hline & & & 200 & 2618.42 & 0.92 & 27.903 & 1.195 \\
\hline \multirow[t]{2}{*}{25} & 120 & 7 & 135 & 1982.94 & 3.9 & 4.985 & 0.256 \\
\hline & & & 139 & 1818.72 & 1.7 & 10.489 & -0.128 \\
\hline \multirow[t]{2}{*}{26} & 130 & 0 & 124 & 1622.46 & 1.9 & 8.372 & 2.475 \\
\hline & & & 124 & 1622.46 & 1.95 & 8.157 & 2.091 \\
\hline \multirow[t]{2}{*}{27} & 130 & 1 & 197 & 3013.83 & 1.7 & 17.381 & 0.896 \\
\hline & & & 239 & 3097.51 & 1.95 & 15.573 & -0.046 \\
\hline \multirow[t]{2}{*}{28} & 130 & 3 & 122 & 1596.29 & 2.8 & 5.589 & 0.726 \\
\hline & & & 128 & 1877.33 & 1.95 & 9.439 & 1.793 \\
\hline \multirow[t]{2}{*}{29} & 130 & 5 & 161 & 2100.96 & 5.8 & 3.551 & 0.256 \\
\hline & & & 167 & 2165.01 & 1.4 & 15.161 & 0.043 \\
\hline \multirow[t]{2}{*}{30} & 130 & 7 & 168 & 2447.17 & 2.35 & 10.209 & 5.933 \\
\hline & & & 174 & 2355.74 & 2.45 & 35.532 & 3.03 \\
\hline
\end{tabular}

Sumber : Hasil Penelitian

Pengaruh Temperatur Pemadatan Terhadap Nilai Stabilitas Marshall Analisa Regresi

Perhitungan regresi ada 2 variabel yaitu variabel $\mathrm{X}$ yang berasal dari temperatur pemadatan dan Y yang berasal dari besarnya stabilitas yang terdiri dari 3 sampel. Variabel temperatur pemadatan diregresikan terhadap nilai stabilitas marshall. Contoh perhitungan model regresi dapat dilihat dibawah ini :

Tabel 6. Nilai - nilai Untuk Menentukan Regresi Linier

\begin{tabular}{cccccc}
\hline NO & $\mathrm{X}$ & $\mathrm{Y}$ & $\mathrm{X}^{2}$ & $\mathrm{Y}^{2}$ & $\mathrm{XY}$ \\
\hline 1 & 80 & 1231.34 & 6400 & 1516198.2 & 98507.2 \\
2 & 80 & 1292.99 & 6400 & 1671823.1 & 103439 \\
3 & 90 & 1983.93 & 8100 & 3935978.2 & 178554 \\
4 & 90 & 1905.53 & 8100 & 3631044.6 & 171498 \\
5 & 100 & 1652.74 & 10000 & 2731549.5 & 165274 \\
6 & 100 & 1618.12 & 10000 & 2618312.3 & 161812 \\
7 & 110 & 3579.88 & 12100 & 12815541 & 393787 \\
8 & 110 & 3367.17 & 12100 & 11337834 & 370389 \\
9 & 120 & 2078.15 & 14400 & 4318707.4 & 249378 \\
10 & 120 & 2006.73 & 14400 & 4026965.3 & 240808 \\
11 & 130 & 1622.46 & 16900 & 2632376.5 & 210920 \\
12 & 130 & 1622.46 & 16900 & 2632376.5 & 210920 \\
$\Sigma$ & 1260 & 23961.5 & 135800 & 53868706 & 2555285 \\
\hline
\end{tabular}

Sumber : Hasil Perhitungan

Keterangan :

$\mathrm{Y}=$ stabilitas marshall

$\mathrm{X}=$ temperatur pemadatan

- Menghitung intersep a

$$
\begin{gathered}
a=\frac{(\Sigma Y)\left(\Sigma X^{2}\right)-(\Sigma X)(\Sigma X Y)}{N\left(\Sigma X^{2}\right)-(\Sigma X)^{2}} \\
=\frac{(23961.50)(135800)-(1260)(2555285)}{12(135800)-(1260)^{2}}
\end{gathered}
$$

$$
=816,9817
$$

- Menghitung koefisien regresi b

$$
\begin{gathered}
b=\frac{N(\Sigma X Y)-(\Sigma X)(\Sigma Y)}{N\left(\Sigma X^{2}\right)-(\Sigma X)^{2}} \\
=\frac{12(2555285)-(1260)(23961,50)}{12(135800)-(1260)^{2}} \\
=11,2363
\end{gathered}
$$


- $\quad$ Menemukan persamaan regresi $\mathrm{Y}=\mathrm{a}+\mathrm{bX}$ $\mathrm{Y}=816.9817+11,2363 \mathrm{X}$

- $\quad$ Menghitung harga - harga $\mathrm{Sy}^{2}, \mathrm{Sx}^{2}, \mathrm{Sxy}$

$$
\begin{aligned}
& \Sigma y^{2}=\Sigma Y^{2}-\frac{(\Sigma Y)^{2}}{N} \\
& =53868706-\frac{(23961,60)^{2}}{12}
\end{aligned}
$$

$=6022582,725$

$$
\begin{aligned}
& \Sigma x^{2}=\Sigma X^{2}-\frac{(\Sigma X)^{2}}{N} \\
& =135800-\frac{(1260)^{2}}{12}
\end{aligned}
$$$$
=\frac{3500}{\Sigma x y}=\Sigma X Y-\frac{(\Sigma X)(\Sigma Y)}{N}
$$$$
=2555285-\frac{(1260)(23961,60)}{12}
$$

$=39327$

- Menghitung koefisien determinasi

$$
\begin{aligned}
& R^{2}=\frac{b(\Sigma x y)}{\Sigma y^{2}} \\
& =\frac{11,2363(39327)}{6022582,725}
\end{aligned}
$$

$=0,073$
- Menghitung taraf korelasi

$$
\begin{gathered}
r=\sqrt{\frac{b\left(\sum x y\right)}{\Sigma y^{2}}} \\
=\sqrt{\frac{11,2363(39327)}{6022582,725}} \\
=0,271
\end{gathered}
$$

Dari uji statistik didapat bahwa ada pengaruh akibat variasi temperatur pemadatan terhadap stabilitas pada campuran AC, hal tersebut ditandai dengan adanya kenaikan serta penurunan nilai stabilitas, akan tetapi penurunan pada stabilitas tersebut masih dalam taraf spesifikasi Bina Marga $(\min 800 \mathrm{~kg})$.

\section{Analisis Variansi dan Uji Signifikansi}

Uji statistik dari koefisien ini (analisa variansi dan uji signifikansi) adalah untuk lebih menegaskan hubungan antar variabel dari model yang akan dipilih.

Hasil perhitungan uji signifikan dari model hubungan antara variabel temperatur pemadatan terhadap nilai stabilitas dapat dilihat dalam contoh Tabel 8 .

Tabel 7. Sidik Ragam Regresi dan Uji Simpangan Model Terhadap Stabilitas Marshall

\begin{tabular}{cccccc}
\hline $\begin{array}{c}\text { Sumber } \\
\text { Keragaman }\end{array}$ & $\mathrm{Jk}$ & $\mathrm{db}$ & $\mathrm{Rk}$ & F hitung & F tabel \\
\hline Regresi & 441889.4 & 1 & 441889.408 & 0.792 & $4.96(5 \%)$ \\
Residu & 5580693 & 10 & 558069.332 & & \\
Total & 6022583 & 11 & & & \\
\hline
\end{tabular}

Sumber : Hasil Perhitungan

Dari hasil perhitungan di atas dapat dilihat bahwa $F_{\text {hitung }}<\mathrm{F}_{\text {tabel }}$ pada taraf $5 \%$ sehingga keputusan ujinya adalah $\mathrm{H}_{0}$ diterima dan $\mathrm{H}_{1}$ ditolak, itu menunjukkan bahwa penambahan temperatur pemadatan pada stabilitas Marshall berpengaruh.

\section{Pembahasan}

Stabilitas lapisan perkerasan jalan adalah kemampuan lapisan perkerasan menerima beban lalu lintas tanpa terjadi perubahan bentuk seperti gelombang, alur atupun bleeding. Dari hasil penelitian dapat disimpulkan bahwa terjadi peningkatan nilai stabilitas campuran, dari temperatur pemadatan $80{ }^{\circ} \mathrm{C}$ menghasilkan nilai stabilitas sebesar $1700 \mathrm{~kg}$ menjadi $2250 \mathrm{~kg}$ untuk penambahan temperatur pemadatan $130{ }^{\circ} \mathrm{C}$.

Hal ini menunjukkan bahwa campuran dengan temperatur pemadatan semakin tinggi maka nilai stabilitas yang dihasilkan akan semakin besar.

\section{KESIMPULAN DAN SARAN}

\section{Kesimpulan}

Dari hasil analisa dan pembahasan dapat disimpulkan sbb: 


\section{Stabilitas}

Nilai stabilitas campuran telah mengalami peningkatan dari temperatur pemadatan $80{ }^{\circ} \mathrm{C}$ menghasilkan nilai stabilitas sebesar $1700 \mathrm{~kg}$ menjadi $2250 \mathrm{~kg}$ untuk penambahan temperatur pemadatan $130{ }^{\circ} \mathrm{C}$. Hal ini menunjukkan bahwa campuran dengan temperatur pemadatan semakin tinggi maka nilai stabilitas yang dihasilkan akan semakin besar.

\section{Saran}

Perlu dilakukan penelitian yang mendalam sehingga diharapkan akan didapatkan suatu nilai yang signifikan dalam penggunaan Variasi Temperatur Pemadatan dalam suatu campuran perkerasan.

\section{DAFTAR PUSTAKA}

Ansyori, Alik, 2009, Penggunaan Pertamax Sebagai Modifier pada Lasbutag Untuk Perkerasan Jalan, Laporan Penelitian, DP2P UMM, Malang.

Ansyori, Alik. 2001. Rekayasa Jalan Raya. UMM Press. Malang.

Ansyori, Alik, 2011, Korelasi Antara Penambahan Aspal Minyak Pada Campuran Aspal Beton Hasil Daur Ulang Terhadap Stabilitas Marshall, Laporan Penelitian, DP2P UMM, Malang.

I Wayan Diana, Ir., Drs., 2009. Uji Karakteristik Campuran Aspal Beton Hasil Daur Ulang Dengan Metode Pencampuran Langsung. Jurnal Transportasi, FSTPT. Bandung.

Martiningtyas, Nining.2011. Statistik. Prestasi Pustaka. Jakarta..

Pataras, 2007. Kinerja Aspal Beton Bergrdasi Senjang Menggunakan Lateks Sebagai Bahan Tambahan. Jurnal Transportasi, FSTPT. Bandung.

Sukirman, Silvia. 2009. Campuran Perkerasan Asbuton. Nova. Bandung.

Soeprapto. 2005. Teknik Jalan. Raya. UGM. Yogyakarta. 